REGULAR ARTICLE

\title{
TECHNICAL EFFICIENCY AND IMPACT EVALUATION DIFFERENTIALS BETWEEN THE ADOPTERS AND NON-ADOPTERS OF NERICA IN THE SIX BASELINE STATES IN NIGERIA
}

\author{
Abiodun Elijah OBAYELU ${ }^{* 1}$, John Olatunji ADEOTI ${ }^{2}$, Nguezet Paul Martins DONTSOP ${ }^{3}$
}

\author{
Address: \\ 1 Department of Agricultural Economics and Farm Management, Federal University of Agriculture Abeokuta, Ogun \\ State, Nigeria \\ 2 Nigerian Institute of Social and Economic Research (NISER,) Ibadan, Oyo State, Nigeria \\ 3 International Institute of Tropical Agriculture (IITA), Ibadan, Nigeria \\ *Corresponding author: obayelu@yahoo.com
}

\begin{abstract}
The study examined the adoption rate of New Rice for Africa (NERICA), technical efficiency differentials of production of these varieties between adopters and non-adopters and the determinants. It further analysed the impact of adoption of NERICA on area cultivated, output, yield, expenditure and total income of rice farmers in the NERICA baseline states in Nigeria. To achieve the objectives, it employed the descriptive statistics, stochastic production frontier and counterfactual outcomes framework of modern evaluation technique (the Local Average Treatment Effect) to analyse 621 rice farmers across the six NERICA baseline states in Nigeria in 2012. The findings show that NERICA adopters were more technically efficient than the non-adopters. In addition, adoption of NERICA was found to significantly increase the areas of land cultivated, output, yield, household expenditure, per capita household expenditure and total income among NERICA adopters by $1.2 \mathrm{ha}(\mathrm{p}<0.01), 1998.2 \mathrm{~kg}(\mathrm{p}<0.01), 191.2 \mathrm{~kg} / \mathrm{ha}(\mathrm{p}<0.1), \mathrm{N} 13,222.63 \approx \$ 66.4(\mathrm{p}$ $<0.05), \mathrm{N} 2,015.6 \approx \$ 10.1(\mathrm{p}<0.05)$ and $\mathrm{N} 145,098.7 \approx \$ 728.0(\mathrm{p}<0.01)$ respectively despite their high level of inefficiency (39 percent) by the adopters. The positive impact of NERICA adoption on rice yields, poverty status measured by the per capita household expenditure and total farm income of farmers is a clear indication that NERICA has the potential to increase rice productivity, reduce poverty and food insecurity. NERICA adoption rate will rise if more farmers are aware of the varieties in the study. Farmers who had adopted, and government at all levels should therefore intensify their efforts to encourage others rice farmers possibly through the extension agents on the need to grow NERICA varieties so as to increase rice production level, reduce rice importation and ensure a sustainable rice production.
\end{abstract}

Keywords: Economic benefits, Rice farmers, Counterfactual approach, with and without adoption, Poverty JEL: C21, C30, D24, E23, O31, O32, O33, P51, Q01, Q16, Q55, R39

\section{INTRODUCTION}

Rice has a great economic importance as it serve as a source of income, and a major staple food in most Nigerian homes (Ologbon et al., 2012). Rice is an increasingly important staple and strategic grain crop in Nigeria (NCRI, 2004). The country consumes about five million metric tonnes annually but local production has not been able to meet this need over the years. Therefore, the difference between what is consumed and what is produced is provided through importation of about 2.1 million metric tonnes making the country to spend about N356 billion annually. Even though the country has a potential land area for rice production of about 4.6 billion hectares, only 1.7 million hectares $(35 \%)$ is grown with rice (Imolehin and Wada, 2000) indicating that food sufficiency through rice production has not yet been realized (FRN, 2006). Availability of improved rice varieties and the adoption by the resource-poor rice farmers is therefore very important to achieve food security. There are many varieties of rice grown in Nigeria. Some are considered as "traditional" varieties, while others were introduced from research institutes or imported from Asia as improved varieties (Tijani, 2006). New Rice for Africa (NERICA) varieties development is one of the most significant advances in crop improvement in Africa (Kinkingninhoun-Medagbe et al., 2014).

Development of the NERICA varieties began in 1991, when Africa Rice initiated an interspecific breeding program for the upland ecosystem (Diagne et al., 2010) and released for use in 1996 (IFAD 2011) through Participatory Value Selection (PVS) trials and other extension efforts (Fowler, 2012). NERICA is crossed between the two species, Oryza sativa, Asiandomesticated rice, and Oryza glaberrima, Africandomesticated rice. NERICA varieties mature quickly making them to cope with drought and compete with weeds which act as serious constraints in upland rice farming in West Africa. NERICA is harvested more times a year with an average yields of $1,500 \mathrm{~kg} /$ hectare without 
fertilizers and 2,500 $\mathrm{kg} /$ hectare using fertilizers, and traditional rice yields of $800 \mathrm{~kg} /$ hectare (AfDB, 2014). The improved rice varieties got to Nigeria in 1999 through a three-year Participatory Varietal Selection (PVS) trials program in both upland and lowland ecologies (Tiamiyu, 2008). It was officially release in 2005 and widely disseminated by the Multinational NERICA Rice Dissemination project from 2006 to 2010 . Today, farmers have access to more than 62 varieties of high-yielding rice species produced by research institutes in Nigeria out of which more than eighteen (18) NERICA varieties have been disseminated but most common types grown by farmers are NERICA 1 and NERICA 2. The improved rice varieties were mainly introduced with the main objective to improve rice yield, total farm income and farmers' livelihood when adopted.

This study determined the rate of adoption of NERICA varieties, the technical efficiency and it determinants. In addition, it analysed the impact of adoption of this improved technology on poverty status, area of land cultivated, rice output, rice yield, household expenditure and income of the rice farmers in the study area. Most of the past studies on NERICA in Nigeria (such as: Dontsop et al., 2011; Awotide et al., 2012; Ojehomon et al., 2012) only focused on the impact of NERICA adoption or seed vouchers by using either a state or two states without considering the technical efficiency and its determinants between the adopters and non-adopters. This study is unique by investigating the level of adoption, TE efficiency differentials and the impact of adoption on outcomes such as rice yield, per capita expenditure, and income at the NERICA baseline states after some years of its introduction. The only similar study to this as far as we know was that of Asante et al., (2014) that estimated the impact of adoption of NERICA on the technical efficiency of smallholder farmers in Ghana using cross sectional data.

The study is imperative because it approaches the problem of estimation of adoption rates and their determinants from the perspective of modern evaluation theory as exposed in the treatment effect estimation literature (Imbens and Wooldridge, 2009; Imbens, 2004; Wooldridge, 2002; Heckman and Vytlacil 1999; Angrist et al., 1996). It will contribute to literature on both technical efficiency and impact evaluation in agriculture in developing countries.

\section{DATA AND METHODS}

This work is a cross-sectional study of rice farmers in six states where the NERICA varieties were first disseminated at its official release in 2005 conducted in 2012. The states were: Kaduna (located in the North Western Nigeria), Nasarawa (located in the Northcentral Nigeria), Ondo Osun, Ogun and Ekiti States, all in the Southwestern Nigeria. These six states are also currently participating in the Multinational NERICA Dissemination Project.

This study draws adoption and modern impact evaluation methodology from previous studies (such as: Asante et al., 2014 in Ghana Ojehomon et al., 2012, Awotide et al., 2012, Dontsop 2011 all in Nigeria; Kijima et al., 2011 in Uganda; Diagne et al., 2009a,b;
2006 in Cote D'Ivoire; Diagne et al., 2004 in Guinea; Spencer et al.,2006).

\section{Survey Data}

The paper used farm survey data collected through a semistructured questionnaire and a Focus Group Discussion (FGD) schedule. In each state, one FGD was conducted with selected farmers and their village head (or his representative) across the rice growing communities to obtain prior information on their livelihoods and rice farming system. Members of the group were asked to state the status of the infrastructure in their village, the major livelihood activities in the village, the natural or manmade incentives for rice cultivation in the village, types of rice varieties grown and level of production by varieties, in the village. For each rice variety listed, among the information, the villagers were asked to identify the type of variety, ecology in which the variety is cultivated, when the variety was introduced, if applicable, the person that introduced the variety and the institution where the person comes from, the introduction method used, variety height and cycle. This was followed by questions regarding the characteristics of each variety such as the agronomic and morphological; post-harvest; cooking and organoleptic characteristics of each variety.

The semi-structured questionnaire was administered after the selection of rice farmers in each village. The full list of the village varieties was delivered to each enumerator after the FGD, and each sampled farmer was asked on whether he/she has knowledge of each of the variety listed. If the answer to the question was 'yes', then the farmer was asked whether he or she has cultivated the variety in past five years (2006 to 2011). The knowledge of the variety was defined as a 'yes' answer to the first question and the adoption as the cultivation of the variety. This was followed by questions on the socio-economic and demographic characteristics of each farmer. Data were collected to elicit information on the farmer's socioeconomic condition, the farm's characteristics, participation in the new rice variety selection, and experience with NERICA adoption, farm productivity, and income. Data on the type of rice varieties planted, farmer's knowledge and adoption of rice varieties, inputs use, mode of access to seed and their management, production and agricultural income, non-farm income and assets, food intake, children's schooling and health, etc. were also collected.

\section{Sampling procedure}

A multi-stage random sampling technique was used to select rice farmers from the six baseline states where NERICA dissemination activities have taken place since 2005 in Nigeria. At a first stage, the six states (Kaduna, Nasarawa, Osun, Ekiti, Ondo and Ogun States) were selected purposively because since the official release of NERICA in 2005, no study as far as we know has evaluated the adoption rate of this variety in all the baseline states in Nigeria nor evaluated technical efficiency of adopters compared to the non-adopters. Spencer et al.,(2006); Dontsop (2011) for instance, estimated the adoption rate of NERICA in only three out of the six baseline states (Kaduna and Ekiti by Spencer 
et a1., 2006; Osun State by Dontsop, 2011). It is therefore worthwhile to estimate the adoption rate of NERICA in all the six baseline states and investigate whether farmers who have adopted the improved varieties were technically efficient or not compared to the nonadopters.

In the second stage (due to the difficulties at getting the list of rice-producing farmers in the selected states as a result of lack of rice farmers' census), the lists of all the rice growing Local Government Areas (LGAs) and villages within the LGAs where rice is grown and NERICA seeds have been disseminated were collected from the respective Agricultural Development Programme (ADPs) officers. Two rice producing LGAs were selected per state while the non- rice producing LGAs were not selected. The third stage was a random selection of two villages where NERICA dissemination activities have taken place, known as PVS villages and one non- PVS NERICA village per LGA. That is, for every two NERICA villages selected, one adjacent village (that is within 15 to $20 \mathrm{~km}$ ) where NERICA is yet to be disseminated was also randomly selected as control. The distance was chosen because the closer the non NERICA village is to the NERICA village, the greater the possibility of farmers' knowledge of the variety through other means apart from official means of dissemination. In each state, six villages were selected. The chance of selecting a non-PVS village that vicinity.

The fourth stage of sampling involved the random selection of at least a hundred (100) rice farmers in each was based on the selection of a NERICA village within

of the selected states. A total of 621 rice farmers were selected from the list of rice farmers in selected villages based on the availability of rice farmers (Table 1). The sample size on the population size of rice farmers would have been used but this was not available.

\section{Analytical Techniques}

In order to address the objectives of this study, both descriptive and econometrics analytical tools (Stochastic Production Frontier (SPF) and Local Average Treatment Effect (LATE)) were employed. Descriptive statistics such as measures of central tendency (mean and standard deviation) as well as frequency distribution tables were used where necessary in order to provide insight into the distribution of socioeconomic and demographic characteristics of farmers in the research sample. Technical efficiency and its determinants of adopters of NERICA and non-adopters were analysed with SPF and Tobit models. The Cobb-Douglas production function provides an adequate representation of the production technology.

\section{Technical Efficiency}

The Technical Efficiency (TE) is defined in terms of the ratio of the observed output $\left(\mathrm{Y}_{\mathrm{i}}\right)$ to the corresponding frontier output $\left(\mathrm{Y}^{*}\right)$, conditioned on the level of inputs used by the farm (Battese and Coelli, 1995; Essilfie et al., 2011). This is mathematically expressed as (Eq.1).

$$
T E=\frac{Y_{i}}{Y_{i}^{*}}
$$

Table 1: Distribution of the research sample rice farmers and retrieved questionnaires

\begin{tabular}{|c|c|c|c|c|c|}
\hline State & LGA & $\begin{array}{l}\text { Selected villages } \\
\text { PVS villages }\end{array}$ & Non-PVS villages & $\begin{array}{r}\text { No. of } \\
\text { respondents } \\
\text { selected }\end{array}$ & $\begin{array}{r}\text { No. of retrieved } \\
\text { questionnaires }\end{array}$ \\
\hline \multirow[t]{2}{*}{ Kaduna } & Kagarko & $\begin{array}{l}\text { Jere (21) } \\
\text { Kagarko (21) }\end{array}$ & Sabo- Iche (17) & 59 & 109 \\
\hline & Igabi & $\begin{array}{l}\text { SabongeriGirku (17) } \\
\text { Gefe (17) }\end{array}$ & Wusa (16) & 50 & \\
\hline \multirow[t]{2}{*}{ Nasarawa } & Lafia & $\begin{array}{l}\text { Igibi (17) } \\
\text { Mararaba (17) }\end{array}$ & Assakio (18) & 52 & 104 \\
\hline & Obi & $\begin{array}{l}\text { Obi (17) } \\
\text { Ikosege (17) }\end{array}$ & Agwatashi (18) & 52 & \\
\hline \multirow[t]{2}{*}{ Ekiti } & Gbonyin & $\begin{array}{l}\text { Aisegba-Reserve (13) } \\
\text { Agbado-Ipole (10) }\end{array}$ & Agbado (26) & 49 & 103 \\
\hline & Ijero & $\begin{array}{l}\text { Ikoro (31) } \\
\text { Iroko (14) }\end{array}$ & Ikoro (9) & 54 & \\
\hline \multirow[t]{2}{*}{ Ondo } & Akure North & $\begin{array}{l}\text { Ayede-Ogbese (10) } \\
\text { Araromi (32) }\end{array}$ & Eleyowo (22) & 64 & 105 \\
\hline & Akure South & $\begin{array}{l}\text { Adofure (14) } \\
\text { Aule (11) }\end{array}$ & Aule (16) & 41 & \\
\hline \multirow[t]{2}{*}{ Ogun } & Obafemi/Owode & $\begin{array}{l}\text { Kajola (18) } \\
\text { Mokoloki (18) }\end{array}$ & Mogbara (20) & 56 & 100 \\
\hline & Ewekoro & $\begin{array}{l}\text { Obada-Oko (15) } \\
\text { Asipa-Ilao (14) }\end{array}$ & Oluwaji (15) & 44 & \\
\hline \multirow[t]{2}{*}{ Osun } & Oriade & $\begin{array}{l}\text { Akola (17) } \\
\text { Erin-Ijesa (16) }\end{array}$ & Erin-Oke (17) & 50 & 100 \\
\hline & Atakumosa & $\begin{array}{l}\text { Maika (17) } \\
\text { Aba-Hitila (16) }\end{array}$ & Oke-Aba (17) & 50 & \\
\hline Total & & & & & 621 \\
\hline
\end{tabular}

Note: Figure in parenthesis represent the number of sampled farmers 
Where $Y_{i}$ is expresssed as (Eq. 2).

$Y_{i}=f\left(X_{i j} ; \beta_{j}\right) \exp \left(V_{i}-U_{i}\right)$

For this study the following Cobb-Douglas stochastic frontier production function was specified as (Eq. 3).

$\operatorname{Ln} Y_{i}=\beta_{0}+\beta_{j} \operatorname{Ln} X_{i j}+V_{i}-U_{i}$

Where

$Y_{i}$ Output $(\mathrm{Kg})$ for the $i^{\text {th }}$ farmer

$\beta_{0}$ Constant term

Ln Natural logarithm

$\beta_{j}$ Unknown parameters to be estimated

$X_{i j}$ the $j^{\text {th }}$ input $(\mathrm{j}=1-5)$ used by $i^{\text {th }}$ farmer. $X_{1}$ is labour used (person-hours); $X_{2}$ is quantity of seed used $(\mathrm{kg}) ; X_{3}$ is the quantity of fertilizer used $(\mathrm{kg}) ; X_{4}$ is the herbicide used (lire); $X_{5}$ is farm size used for rice production (ha) $V_{i}-U_{i}$ Composite error term.

$V_{i}$ Random error not under the control of the famers, assumed to be independently and identically distributed as $\mathrm{N}\left(0, \delta_{u}^{2}\right)$ independent of $U_{i}$

$U_{i} \quad$ Non-negative random variable associated with technical inefficiency (1-TE) effects of production of the farmers involved. This is identically and independently distributed as a truncated normal. The truncations are at zero of the normal distribution (Battese and Coelli, 1995)

\section{Tobit regression model}

We used Tobit regression model to determine factors affecting the TE inefficiency $\left(U_{i}\right)$ based on Battese and Coelli (1995). The model is specified as (Eq. 4).

$U_{i}=\delta_{0}+\delta_{j} Z_{i j}+d_{i}$

Where the independent variables are as follows;

$\mathrm{Z}_{1}$ Sex (male $=1$, otherwise 0 )

$\mathrm{Z}_{2}$ Age (years)

$\mathrm{Z}_{3}$ Marital status $(1=$ married, $0=$ Divorced $)$

$\mathrm{Z}_{4}$ Household size (number)

$\mathrm{Z}_{5}$ Educational level (years)

$\mathrm{Z}_{6}$ Years rice farming experience (years)

$\mathrm{Z}_{7}$ Assets owned (N)

$\mathrm{Z}_{8}$ Access to credit visits (Access $=1$; otherwise 0)

$\mathrm{Z}_{9}$ Access to extension visits (Access $=1$; otherwise 0 )

$d_{i}$ Error term, independent and identically distributed and obtained by truncation of the normal distribution with zero mean and constant variance $\left(\delta^{2}\right)$

$\delta_{j}$ Unknown parameters to be estimated

\section{Counterfactual estimations}

The impact estimates are based on the LATE following Imbens and Angrist, (1994). The paper used the Local Average Response Function (LARF) to estimate LATE because the instruments (NERICA knowledge and access to NERICA seed were not randomly distributed in the population). The study assessed the causal effects of NERICA adoption on rice yield total quantity of rice in $\mathrm{kg}$ harvested per area planted), output, household expenditure, per capita expenditure and farm total income.
To control for differences in socio-demographic and environmental characteristics of adopters and nonadopters, and to enable a causal interpretation of NERICA adoption on the variables of interest, the study used the counterfactual outcome framework to control for such differences.

The counterfactual framework detects two important sources of bias in the estimation of treatment effects These include the initial differences between adopters and nonadopters in the absence of treatment, and the difference between the two groups in the potential effect of the treatment. The parameters of estimation are the ATE which is the expected effect of treatment on a randomly drawn person from the population, the average effect of the treatment on the treated (ATT) which represents the mean effect for those who actually participated in the treatment, and the average effect of treatment on the untreated (ATU) which measures the expected treatment effect for an individual drawn from the population of nonparticipants. Two alternative statistical independence assumptions were made to identify ATE, ATT and ATU following Imbens and Wooldrige, (2009); de Janvry et al., (2010). The first is the unconditional independence assumption: this assumption states that the population distribution is independent of outcome of exposure to treatment. Under this assumption, ATE, ATT and ATU were identified by the mean difference of observed outcomes of adopters and non-adopters. The second assumption is the conditional independence assumption also called "selection on observables". The population distribution is independent of the outcome of exposure to treatment conditional on some observed components. Under this assumption the conditional mean treatment effects are all identified by the conditional mean difference of observed outcomes.

By the counterfactual outcome framework a randomly selected rice producing household had two potential outcomes of adopting NERICA varieties. This is specified as (Eq. 5).

$Y=Y_{1}$ if $T=1$ and $Y=Y_{0}$ if $T=0$

In Eq. 5, $\mathrm{Y}$ is the outcome of interest as a result of exposure to treatment which in our study include, rice output, productivity, expenditure, poverty reduction, income. $\mathrm{T}$ is the adoption status. For the sample of randomly selected rice producing households the average effect of adoption, which is also known as average treatment effect, ATE, is generally specified as (Eq. 6)

$A T E=E\left(Y_{1}-Y_{0}\right)$

Differences in knowledge and access to information, physical accessibility as well as socioeconomic condition were expected to present unequal opportunities for adoption (Tambo and Abdoulaye, 2011). The impact parameter given adoption status, also known as the average treatment effect on the treated, ATT or ATE1, is specified as (Eq. 7).

$\left.A T T=E\left(Y_{1}-Y_{0}\right) \mid T=1\right)=E\left(Y_{1} \mid \mathrm{T}=1\right)$ 
$Y_{1}, Y_{0} \quad$ Outcome of exposure to treatment, $\mathrm{T}$ treatment variable status; $(\mathrm{T}=1)$ Exposure to treatment. ATU can be expressed as (Eq. 8).

$$
\left.A T U=E\left(Y_{1}-Y_{0}\right) \mid T=0\right)=E\left(Y_{1} \mid \mathrm{T}=0\right)
$$

Where

ATU or ATE0 average treatment effect on the untreated and $(\mathrm{T}=0)$ non exposure to treatment

Once a consistent estimate of ATE, ATE1 and the probability of exposure $\mathrm{P}(\mathrm{T}=1)$ is obtained, the expected "non-exposure" bias (NEB) is defined as (Eq. 9).

$\mathrm{NEB}=\mathrm{P}(\mathrm{T}=1) \times$ ATT ATE

JEA is the joint exposure and adoption parameter and is consistently estimated by the sample average of observed adoption outcome value. This is estimated as (Eq. 10).

$J E A=\frac{1}{n} \sum_{\mathrm{i}=1}^{\mathrm{n}} \mathrm{y}_{\mathrm{i}}$

The Population Selection Bias (PSB) is estimated as (Eq. $11)$.

\section{$\mathrm{PSB}=\mathrm{ATU}-\mathrm{ATE}$}

In this study access to the NERICA varieties was considered the most satisfactory condition for adoption (use of at least one NERICA variety in the specified cropping season). However, it was possible that some farmers had access to the seeds but did not plant the seeds. This implies that some farmers may have complied while others did not. In this case the impact on the farmers who received the seeds and subsequently planted, which is the local average treatment effect "LATE", is a more useful estimate of impact. The non-parametric local average treatment effect (LATE) framework was used to estimate the causal effect of the adoption of NERICA on total farm income, yield, and expenditure. Because the adoption variable is endogenous, the LATE parameter was estimated with the combined variable of awareness and access to seed of a NERICA variety as instrumental variable. With this non-random instrumental variable in the target population, the OLS with interaction local average response function (LARF) was used to estimate the LATE parameter for the impact of NERICA varieties. The LATE parameter is estimated as (Eq.12).

$$
L A T E=E\left(Y_{1}-Y_{0}\right) \mid P=1, T=1
$$

Poverty level: This was calculated for the adopters and non-adopters using the Foster-Greer-Thorbecke poverty indices (FGT, 1984). The relative poverty line of $2 / 3$ of the mean per capita income was used to generate the aggregate values of the poverty incidence. The FGT index is estimated as (Eq. 13).

$$
P_{\alpha}=\frac{1}{n} \sum_{i=1}^{q}\left(\frac{Z-Y_{i}}{Z}\right)^{\alpha}
$$

where $\alpha \geq 0$ and takes the values of 0,1 and 2 for poverty incidence, depth and severity respectively; $q$ is the number of people with an income below the poverty line; $Y_{i}$ is the income represented by the total household expenditures of ith household, $n$ is the total population and $Z$ is the poverty line. The definitions of these indices are given below.

When $\alpha=0$, then $P_{\alpha}=P_{0}$ gives the Incidence of Poverty (or poverty headcount Index). This is the share of the population whose income or consumption is below the poverty line, that is, the share of the population that cannot afford to buy a basic basket of goods. Similarly, for nonmonetary indicators the incidence of poverty measures the share of the population that does not reach the defined threshold (for instance, the percentage of the population with less than three years of education).

\section{RESULTS AND DISCUSSION}

\section{Adoption Rate of NERICA Varieties}

Table 2 showed that the actual adoption rate for all the sampled state to be 57 percent. Across the individual states, the actual adoption rate was 77 percent, 67 percent, 62 percent, 62 percent, 47 percent and 8percent in Ondo, Ekiti, Nasarawa, Ogun, Kaduna and Osun States respectively. This rate is too low but is in agreement with the finding of Ajewole, et al., (2015). The potential adoption rate (ATE), which represents the true demand for NERICA varieties by the target population was estimated to be 80 percent for the study area. Specifically, 98 percent, 90 percent, 86 percent, 84 percent, 82 percent and 13 percent in Nasarawa, Ondo, Ekiti, Ogun, Kaduna, and Osun States respectively. This suggest that if the whole population was aware of, and have access to NERICA seed before the survey, the NERICA adoption rate in the study area could have been 80 percent instead of the actual 57 percent. Thus, for entire study area (six states), the estimate of the population adoption gap was accordingly 23 percent, and statistically significant at 1 percent level. The corresponding estimates of the population adoption gap (that is, the non-awareness bias) for Nasarawa, Kaduna, Ogun, Ekiti, Ondo, and Osun States are 36 percent, 35 percent, 22 percent, 19 percent, 14 percent, and 5 percent respectively, and all are statistically significant at 1 percent level. At the time of this study, the adoption rates among the NERICA exposed subpopulation (ATE1) in the study area was 81 percent while in Nasarawa, Ondo, Ekiti,Ogun, Kaduna, and Osun States, the adoption rate were estimated to be 98 percent, 90 percent, 86 percent, 85 percent, 83 percent and 12 percent respectively. 
Table 2: Estimation of Population Adoption Incidence Rates

\begin{tabular}{|c|c|c|c|c|c|c|c|}
\hline Variables & Ekiti & Kaduna & Nassarawa & Ogun & Ondo & Osun & Pooled sample \\
\hline ATE & $0.859 * * *(0.038)$ & $0.815 * * *(0.041)$ & $0.980 * * *(0.017)$ & $0.839 * * *(0.043)$ & $0.904 * * *(0.031)$ & $0.132 * * *(0.034)$ & $0.799 * * *(0.017)$ \\
\hline ATE1 & $0.859 * * *(0.038)$ & $0.834 * * *(0.041)$ & $0.983 * * *(0.015)$ & $0.852 * * *(0.039)$ & $0.904 * * *(0.031)$ & $0.120 * * *(0.031)$ & $0.810 * * *(0.015)$ \\
\hline ATE0 & $0.860 * * *(0.042)$ & $0.790 * * *(0.063)$ & $0.976 * * *(0.021)$ & $0.806 * * *(0.058)$ & $0.908 * * *(0.034)$ & $0.157 * * *(0.051)$ & $0.775 * * *(0.025)$ \\
\hline JAA & $0.667 * * *(0.029)$ & $0.467 * * *(0.023)$ & $0.624 * * *(0.010)$ & $0.622 * * *(0.029)$ & $0.766 * * *(0.026)$ & $0.084 * * *(0.022)$ & $0.569 * * *(0.011)$ \\
\hline GAP & $-0.192 * * *(0.009)$ & $-0.348 * * *(0.028)$ & $-0.356 * * *(0.008)$ & $-0.218 * * *(0.016)$ & $-0.138 * * *(0.005)$ & $-0.048 * * *(0.015)$ & $-0.230 * * *(0.007)$ \\
\hline PSB & $-0.000(0.004)$ & $0.019(0.018)$ & $0.003(0.004)$ & $0.012(0.009)$ & $-0.001(0.002)$ & $-0.012(0.011)$ & $0.010 *(0.005)$ \\
\hline \multicolumn{8}{|l|}{ Observed } \\
\hline $\mathrm{NE} / \mathrm{N}$ & $0.777 * * *(0.412)$ & $0.560 * * *(0.048)$ & $0.635 * * *(0.047)$ & $0.730 * * *(0.045)$ & $0.848 * * *(0.035)$ & $0.700 * * *(0.046)$ & $0.703^{* * *}(0.020)$ \\
\hline $\mathrm{NA} / \mathrm{N}$ & $0.631 * * *(0.048)$ & $0.468 * * *(0.048)$ & $0.644 * * *(0.048)$ & $0.620 * * *(0.0488)$ & $0.762 * * *(0.042)$ & $0.060 * * *(0.024)$ & $0.569 * * *(0.021)$ \\
\hline $\mathrm{NA} / \mathrm{NE}$ & $0.813 * * *(0.062)$ & $0.836 * * *(0.086)$ & $0.985 * * *(0.076)$ & $0.849 * * *(0.067)$ & $0.899 * * *(0.049)$ & $0.086 * * *(0.034)$ & $0.809 * * *(0.030)$ \\
\hline $\mathrm{N}$ & 103 & 109 & 101 & 100 & 105 & 100 & 552 \\
\hline $\mathrm{NE}$ & 80 & 61 & 66 & 73 & 89 & 70 & 388 \\
\hline NA & 65 & 51 & 65 & 62 & 80 & 6 & 314 \\
\hline
\end{tabular}

Note: Figures in parentheses are standard errors.

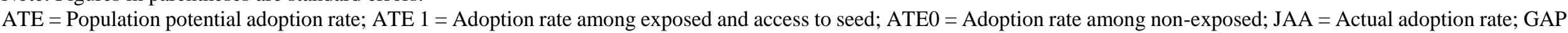
$=\mathrm{JAA}-\mathrm{ATE} ; \mathrm{PBS}=$ Population selection bias $; \mathrm{N}=$ number observed

$\mathrm{NE}=$ number of exposed; $\mathrm{NA}=$ number of adopters

$* * *=\mathrm{p}<0.01 \quad * *=\mathrm{p}<0.05 \quad *=\mathrm{p}<0.10$ 


\section{Technical Efficiency}

The mean technical efficiency of adopters of New Rice for Africa (NERICA) and non-adopters were $61 \%$ and 52\% respectively (Table 5). The mean technical efficiency of adopter is higher than $57 \%$ reported by Ayinde et al., (2009) in Nigeria and lower than the mean TE of 63\%, $65 \%$ of improved rice varieties reported by Okoruwa and Ogundele (2004), Tiamiyu et al., (2010) across four major rice producing states (Kaduna, Niger, Ebonyi and Ekiti) in Nigeria and in the savannah zone of Nigeria respectively. The mean TE from this study implied that those that adopted NERICA were only able to obtain $61 \%$ output of the maximum attainable with given input levels while the non-adopters have 52\% optimal outputs from a given mix of production inputs. It was also observed that about $39 \%$ and $38 \%$ of the sampled farmers who were adopters and non-adopters of NERICA respectively operate below the mean efficiency score of 0.61 and $51 \%$. This variation was confirmed by the value of gamma $(\gamma)$ which was 0.54 for adopters and 0.83 for the non-adopters suggesting that $54 \%$ and $83 \%$ variation in output by adopters and non-adopters was respectively due to the differences in technical efficiencies of farm household. The output of rice by NERICA adopters was found to be significantly influenced by labour used, quantity of seed, quantity of fertilizer and farm size. This indicates that as each of these variables are increased, ceteris paribus rice output of NERICA adopters increases. Labour was probably significant because rice production is the most labour intensive activity when compared to other cereals. The positive coefficient and significant of farm size at $1 \%$ level by adopters and non-adopters implied that an increase in the size of the farm by a hectare increased farm technical efficiency by $0.4 \%$ (Tables 3 and 4 ).

\section{Determinants of Technical inefficiency}

Results in Table 6 shows that differences in TE between adopters and non-adopters exist in the NERICA baseline states in Nigeria. Tables 7 and 8 show the results of the inefficiency model in of rice production by NERICA adopters and non-adopters respectively in the study areas.
Rice production by adopters of NERICA was observed to be positively and significantly affected by the sex of the rice farmers, age, marital status, household size, years of education and extension visits while the significant factors affecting non-adopters were: the sex, marital status, household size, assets owned and extension visits (Table 8 ). The positive sign of the parameters in the results means that the associated variable has a negative effect on technical efficiency. The coefficient of sex was estimated to be negative as expected and statistically significant $(\mathrm{p}<0.01)$ in production of rice by the adopters and nonadopters. The implication is that female rice farmers tend to be more efficient in rice production. Similarly, the positive sign of the parameter of this variable marital status both for the adopters and non-adopters showed that marriage increases inefficiency and make rice farmers less technically efficient than the single. The coefficient of the age of adopters estimated to be positive and statistically significant $(\mathrm{p}<0.05)$ revealed that that older farmers who adopt NERICA tend to be less efficient in rice production. This might be as a results of their long traditional believe in the cultivation of the traditional rice varieties. Contrary to the a priori expectation, access to extension visit has a positive coefficient to farmers' inefficiency. This implied that increasing access to extension visits will statistically and significantly reduce efficiency of the farmers (NERICA adopters and non-adopters).

\section{Impact of NERICA adoption on rice farm household poverty status}

Table 9 showed that 53 percent of rice farmers in the research sample are non-poor. As depicted in Table 10, the incidence (head count), depth and severity of poverty are $0.4670,0.1591$ and 0.0790 respectively. A comparative analysis of NERICA adopters and non-adopters in Table 11 shows that the poverty incidence, depth and severity are lower by 28 percent, 17 percent and 26 percent respectively among NERICA adopters. It is thus apparent that the incidence, depth, and severity of poverty are less among the adopters than the non-adopters in the study area.

Table 3: Maximum likelihood estimates of stochastic frontier for adopters

\begin{tabular}{|c|c|c|c|c|}
\hline Variables & Coefficient & Standard Error & t-ratio & $\mathrm{p}>|\mathrm{z}|$ \\
\hline Ln labour used & $0.1586 * * *$ & 0.0185 & 8.5900 & 0.0000 \\
\hline Ln seeds used & $0.2037 * * *$ & 0.0548 & 3.7200 & 0.0000 \\
\hline Ln fertilizer & $0.0640 * * *$ & 0.0204 & 3.1400 & 0.0020 \\
\hline Ln herbicide used & -0.0074 & 0.0365 & -0.2000 & 0.8390 \\
\hline Ln farm size used & $0.3550 * * *$ & 0.0766 & 4.6400 & 0.0000 \\
\hline Constant & $6.0988 * * *$ & 0.2656 & 22.9600 & 0.0000 \\
\hline Sigma_( $\delta v)$ & 0.6157 & 0.0413 & 0.5399 & \\
\hline 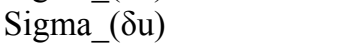 & 0.6718 & 0.0679 & 0.5510 & \\
\hline Sigma_ $\delta^{2}$ & 0.8304 & 0.0818 & 0.6701 & \\
\hline Lambda $(\lambda)$ & 1.0911 & 0.0942 & 0.9065 & \\
\hline $\operatorname{Gamma}(\gamma)$ & 0.5435 & & & \\
\hline Log likelihood function & $-453.4523 * * *$ & 0.0000 & & \\
\hline
\end{tabular}

Note: $* * *$ Significance at $\mathrm{p}<0.01$ 
Table 4: Maximum likelihood estimates of stochastic frontier for non-adopters

\begin{tabular}{|c|c|c|c|c|}
\hline Variables & Coefficient & Standard Error & t-ratio & $\mathrm{p}>|\mathrm{z}|$ \\
\hline Ln labour used & $0.1086^{* * *}$ & 0.0310 & 3.5100 & 0.0000 \\
\hline Ln seed used & $0.3399 * * *$ & 0.0759 & 4.4800 & 0.0000 \\
\hline Ln fertilizer & 0.0290 & 0.0254 & 1.1400 & 0.2530 \\
\hline Ln herbicide used & 0.0584 & 0.0544 & 1.0700 & 0.2830 \\
\hline Ln farm size used & $0.4209 * * *$ & 0.1033 & 4.0800 & 0.0000 \\
\hline Constant & $5.8397 * * *$ & 0.4318 & 13.5200 & 0.0000 \\
\hline Sigma_( $\delta v)$ & 0.4224 & 0.0618 & 0.3171 & \\
\hline Sigma_(du) & 0.9175 & 0.1057 & 0.7320 & \\
\hline Sigma_ $\delta^{2}$ & 1.0202 & 0.1770 & 0.6734 & \\
\hline Lambda $(\lambda)$ & $2.1719^{*}$ & 0.1443 & 1.8891 & \\
\hline $\operatorname{Gamma}(\gamma)$ & 0.8251 & & & \\
\hline Log likelihood function & $-206.5447 * * *$ & 0.0000 & & \\
\hline
\end{tabular}

Note: $* * *$ Significant at $\mathrm{p}<0.01$

Table 5: Frequencies distribution of TE among adopters and non-adopters

\begin{tabular}{lcccc}
\hline & \multicolumn{2}{l}{ Adopters } & \multicolumn{3}{c}{ Non-Adopters } \\
\cline { 2 - 5 } Level of Frequency & Frequency & Percentage & Frequency & Percentage \\
\hline$<0.50$ & 73 & 20.7 & 61 & 38.1 \\
$0.51-0.55$ & 32 & 9.1 & 12 & 7.5 \\
$0.56-0.60$ & 33 & 9.4 & 12 & 7.5 \\
$0.61-0.65$ & 52 & 14.8 & 17 & 10.6 \\
$0.66-0.70$ & 51 & 14.5 & 16 & 10.0 \\
$0.71-0.75$ & 49 & 13.9 & 12 & 7.5 \\
$0.76-0.80$ & 42 & 11.9 & 15 & 9.4 \\
$0.81-0.85$ & 16 & 4.5 & 12 & 7.5 \\
$0.86-0.90$ & 4 & 1.1 & 3 & 1.9 \\
$0.91-0.95$ & - & - & - & - \\
$0.96-1.00$ & - & - & - & - \\
Mean TE & 0.6064 & & 0.5285 & \\
Std. Deviation & 0.1674 & & 0.2335 & \\
Minimum TE & 0.0014 & & 0.0024 & \\
Maximum TE & 0.8755 & & 0.8715 & \\
\hline
\end{tabular}

Source: Computed from MLE Results

Table 6: Test of Hypothesis

\begin{tabular}{lrrrrr}
\hline Variable & Obs & Mean TE & Difference TE & Std. Dev. & t-value \\
\hline Adopters & 352 & 0.6064 & \multirow{2}{*}{$0.0182 * * *$} & 0.1674 & \multirow{2}{*}{4.2849} \\
Non adopters & 160 & 0.5285 & & 0.2335 & \\
\hline
\end{tabular}


Table 7: Determinants of technical inefficiency of adopters of NERICA

\begin{tabular}{lccr}
\hline Variables & Coefficient & Standard Error & t-ratio \\
\hline Sex $\left(\mathrm{Z}_{1}\right)$ & $4.6128^{* * *}$ & 1.6931 & 2.7244 \\
Age $\left(\mathrm{Z}_{2}\right)$ & $0.1244^{* *}$ & 0.0559 & 2.2236 \\
Marital status $\left(\mathrm{Z}_{3}\right)$ & $4.6586^{*}$ & 2.5693 & 1.8132 \\
Household size $\left(\mathrm{Z}_{4}\right)$ & $0.2207^{*}$ & 0.1218 & 1.8124 \\
Year of education $\left(\mathrm{Z}_{5}\right)$ & $0.3267^{* *}$ & 0.1345 & 2.4295 \\
Years of rice farming experience $\left(\mathrm{Z}_{6}\right)$ & 0.0324 & 0.0270 & 1.2009 \\
Assets owned $\left(\mathrm{Z}_{7}\right)$ & -0.0742 & 0.7624 & -0.0973 \\
Access to credit $\left(\mathrm{Z}_{8}\right)$ & 0.3955 & 0.8465 & 0.4672 \\
Access to extension visit $\left(\left(\mathrm{Z}_{9}\right)\right.$ & $5.0444 * *$ & 2.5611 & 1.9696 \\
Access to information on $\mathrm{NERICA}\left(\mathrm{Z}_{10}\right)$ & -0.5411 & 0.8166 & -0.6626 \\
Constant & -23.8259 & 10.7392 & -2.2186 \\
\hline Note: $* * *$ Significant at $\mathrm{p}<0.01, * *$ Significant at $\mathrm{p}<0.05, * * *$ Significant at $\mathrm{p}<0.10$.
\end{tabular}

Table 8: Determinants of technical inefficiency of non-adopters of NERICA

\begin{tabular}{lccr}
\hline Variables & Coefficient & Standard Error & t-ratio \\
\hline Sex $\left(\mathrm{Z}_{1}\right)$ & $2.2768^{* * *}$ & 1.1136 & 2.0445 \\
Age $\left(\mathrm{Z}_{2}\right)$ & 0.0009 & 0.0309 & 0.0281 \\
Marital status $\left(\mathrm{Z}_{3}\right)$ & $4.1046^{*}$ & 2.1818 & 1.8813 \\
Household size $\left(\mathrm{Z}_{4}\right)$ & $0.5391^{* * *}$ & 0.1960 & 2.7507 \\
Year of education $\left(\mathrm{Z}_{5}\right)$ & -0.0105 & 0.0581 & -0.1808 \\
Years of rice farming experience $\left(\mathrm{Z}_{6}\right)$ & -0.0141 & 0.0331 & -0.4249 \\
Asset owned $\left(\mathrm{Z}_{7}\right)$ & $2.0578^{* *}$ & 0.9414 & 2.1860 \\
Access to credit $\left(\left(\mathrm{Z}_{8}\right)\right.$ & -0.4869 & 0.8040 & -0.6056 \\
Access to extension visits $\left(\left(\mathrm{Z}_{9}\right)\right.$ & $3.1385^{*}$ & 1.8537 & 1.6931 \\
Access to information on $\mathrm{NERICA}\left(\mathrm{Z}_{10}\right)$ & 1.6440 & 1.0724 & 1.5331 \\
Constant & -7.5723 & 5.0179 & -1.5091 \\
\hline$* *$ Significant at $\mathrm{p}<0.01, * *$ Significant at $\mathrm{p}<0.05 * * *$ Significant at $\mathrm{p}<0.10$ &
\end{tabular}

$* * *$ Significant at $\mathrm{p}<0.01, * *$ Significant at $\mathrm{p}<0.05, * * *$ Significant at $\mathrm{p}<0.10$

Table 9: Distribution of respondents by poverty status

\begin{tabular}{llc}
\hline Poverty status & Frequency & Percentage \\
\hline Non-poor & 331 & 53.30 \\
Poor & 290 & 46.70 \\
Total & 621 & 100.00 \\
\hline
\end{tabular}

Table 10: Poverty profile of rice farmers by states in the study area

\begin{tabular}{lccc}
\hline States & Head count $\left(\mathrm{P}_{0}\right)$ & Poverty depth $\left(\mathrm{P}_{1}\right)$ & Poverty severity $\left(\mathrm{P}_{2}\right)$ \\
\hline Ekiti & $0.3786(0.0506)$ & $0.1309(0.0229)$ & $0.0611(0.0143)$ \\
Kaduna & $0.4312(0.05170$ & $0.1218(0.0189)$ & $0.0468(0.0102)$ \\
Nassarawa & $0.4712(0.0501)$ & $0.2313(0.0350)$ & $0.1489(0.0313)$ \\
Ogun & $0.7100(0.0507)$ & $0.2662(0.02613)$ & $0.1220(0.0179)$ \\
Ondo & $0.2381(0.0435)$ & $0.0769(0.0190)$ & $0.0393(0.0152)$ \\
Osun & $0.5900(0.0529)$ & $0.1330(0.0220)$ & $0.0581(0.0176)$ \\
Pooled sample (Nigeria) & $0.4670(0.0238)$ & $0.1591(0.0139)$ & $0.0790(0.0111)$ \\
\hline
\end{tabular}

Note: Figures in parentheses are standard deviations

Table 11: Poverty profile of NERICA adopters and non-adopters

\begin{tabular}{lrrr}
\hline Group & Head count $\left(\mathrm{P}_{0}\right)$ & Poverty depth $\left(\mathrm{P}_{1}\right)$ & Poverty severity $\left(\mathrm{P}_{2}\right)$ \\
\hline Non-Adopters $(\mathrm{n}=289)$ & $0.5294(0.0329)$ & $0.17156(0.0179)$ & $0.0873(0.0145)$ \\
Adopters $(\mathrm{n}=332)$ & $0.4134(0.0299)$ & $0.1466(0.0157)$ & $0.0693(0.0112)$ \\
Percentage change & 28.1 & 17.0 & 26 \\
\hline Ne: & &
\end{tabular}

Note: Figures in parentheses are standard deviations 
Table 12: Observed sample mean outcomes and differences

\begin{tabular}{cllllll}
\hline Variables & $\begin{array}{l}\text { Area } \\
\text { cultivated } \\
\text { (ha) }\end{array}$ & $\begin{array}{l}\text { Rice output } \\
(\mathrm{Kg})\end{array}$ & $\begin{array}{l}\text { Yield } \\
(\mathrm{kg} / \mathrm{ha})\end{array}$ & $\begin{array}{l}\text { Household } \\
\text { expenditures }(\mathrm{N})\end{array}$ & $\begin{array}{l}\text { Per } \\
\text { expenditure }(\mathrm{N} \\
\text { /person) }\end{array}$ & $\begin{array}{l}\text { Total income } \\
(\mathrm{N})\end{array}$ \\
\hline Diffmo & $1.1459^{* * *}$ & $1998.1850^{* * *}$ & $191.2394 *$ & $13222.63 * *$ & $2015.5850 * *$ & $145098.7000 * * *$ \\
& $(0.1666)$ & $(314.6898)$ & $(99.1622)$ & $(5667.4740)$ & $(897.6829)$ & $(22449.9900)$ \\
mo_N1 & $2.6029 * * *$ & $4339.8080^{* * *}$ & $1412 * * *$ & $76864 * * *$ & $11723.92 * * *$ & $362640.3000 * * *$ \\
& $(0.1284)$ & $(249.6200)$ & $(69.5949)$ & $(3975.9550)$ & $(675.5535)$ & $(17076.2500)$ \\
m0_N0 & $1.4589 * * *$ & $2341.623 * * *$ & $1220.99 * * *$ & $63641.9300 * * *$ & $9708.334 * * *$ & $217541.6000 * * *$ \\
& $(0.1061)$ & $(191.6234)$ & $(70.6378)$ & $(4038.8180)$ & $(591.1532)$ & $(14574.0000)$ \\
N & 606 & 488 & 618 & 616 & 604 & 608 \\
N1 & 323 & 260 & 329 & 327 & 321 & 322 \\
\hline Note* $* * * * \mathrm{p}<0.01$ & $* *=\mathrm{p}<0.05$ & $*=\mathrm{p}<0.10$ & & & \\
\hline
\end{tabular}

Note: $* * *=\mathrm{p}<0.01$
Robust standard errors in parenthesis, $\$ 1=\mathrm{N} 199.00$

Diffmo mean difference, mo_N1 adopters, N number observed, m0_N0 non-adopters, N1 = Number of treated

Impact of the adoption of NERICA varieties on area of land cultivated, rice output, yield, household expenditure, per capita expenditure and total farm income

Table 12 shows that the adoption of NERICA had significantly increased the areas of land cultivated, rice output, yield, household expenditure, per capita expenditure and total income among NERICA adopters by 1.2ha (p < 0.01), 1998.2kg ( $<<0.01), 191.2 \mathrm{~kg} / \mathrm{ha}(\mathrm{p}<$ 0.1 ), N13,222.6 (equivalent to \$66.3) ( $\mathrm{p}<0.05)$, $\mathrm{N} 2015.59$ (equivalent to $\$ 10.1)(\mathrm{p}<0.05)$ and N145098.7 (equivalent to $\$ 728.0$ ) ( $\mathrm{p}<0.01$ ) respectively. The significance increase in farm size cultivated between the NERICA adopters and non-adopter was in line with the findings of Diagne $\boldsymbol{e t}$ al., (2009a) in a similar study in Benin Republic and Mendola (2007) in Bangladesh. The two different studies found a significant increase in farm size between technology adopters and non-adopters with the adopters cultivating larger farm area. The estimated sample mean yield of 1.4 tonnes per hectare by NERICA adopters in the research sample is higher than the average yield of 0.995 tonnes per hectare for upland varieties reported by Dalton and Guei (2003) from a sample of 50 farmers from some of the PVS villages in the forest zone of Cote d'Ivoire; 1.2 tonnes per hectare obtained from a similar study by Diagne (2006) in Cote d'Ivoire, 0.18 tonnes per hectare from the sampled of 489 rice farmers from three districts-Ejura-Sekyedumase, Hohoe and Tolon-Kumbungu in Ghana (Wiredu et al., 2010), but lower than the average yield of 1.5 tonnes per hectare of upland rice yield in two states (Kaduna and Ekiti) of Nigeria by Spencer $\boldsymbol{e t}$ al., (2006); 2.3 tonnes per hectare for NERICA varieties estimated by Kijima et al.,(2006) based on a sample of 254 NERICA farmers in Uganda. The additional yield gain of 0.19 tonnes per hectare was also found to be higher than that of 0.14 tonnes per hectare achieved by rice farmers adopting NERICA varieties in Gambia (Dibba, 2010). Similarly, adoption of NERICA rice had improved the income of rice farmers in the research sample. The LATE estimates in Tables 6 indicate a significantly increased household per capita expenditure of N2,519.2 (\$12.6 at N199 official exchange rate to dollar) or NERICA adopters. This is however lower than N28,739.7 (\$144.2) reported by Ojehomon et al.,(2012) study on the impact of adoption of New Rice for Africa (NERICA) on farmer yield, income and expenditure in Nigeria in 2010.

The results of the disaggregation impact of adoption by the poverty status in Table 13 implied that NERICA adoption positively and significantly $($ at $\mathrm{P}<0.01)$ increased the farm size of the poor adopters by $1.2 \mathrm{ha}$ and that of the non-poor adopters by 0.8 ha. Rice output has also significantly increased for poor adopters by $1993.9 \mathrm{~kg} / \mathrm{ha}$, and among non-poor adopter by $1002.9 \mathrm{~kg} / \mathrm{ha}$ (at $\mathrm{P}<0.1$ ). Also observed was a significant (at $\mathrm{P}<0.01$ ) impact of NERICA adoption on total income. The total income of rice farmers significantly and positively increased by $\mathrm{N} 169,247.7$ (\$849.2/ha among the poor adopters and by $\mathrm{N} 106,7$ (\$5.4) /ha among the non-poor adopters. Contrary to our expectation, there was no significant difference between the yields and the per capita expenditures of the poor adopters and non- adopters.

\section{CONCLUSION AND RECOMMENDATIONS}

This study evaluated the adoption rate of NERICA varieties in the study areas; the technical efficiency of NERICA adopters and non-adopters; and the impact of adoption of the varieties on total farm income, area of rice cultivated, rice yield, per capita expenditure and poverty status of rice farmers. The key findings from the study, the policy implications and recommendations are:

The average farm size of NERICA varieties adopters increased from 1.4 to 2.6ha. This shows that in spite of evident of adoption of NERICA varieties, rice production in Nigeria is still at the small scale level;

The actual adoption rate of NERICA varieties was 57 percent, while the potential adoption rate (ATE) was estimated to be 80 percent in the study area. This suggests that 80 percent of rice farmers would have adopted NERICA varieties if they are fully aware instead of the actual 57 percent. NERICA population adoption gap of 23percent indicates a very high unmet demand for NERICA in Nigeria. It also suggests that there is still a potential to significantly increase NERICA adoption rates in Nigeria. 
Table 13: Differential impact of NERICA adoption on area of land cultivated, rice output, household expenditure, per capita income and total income by poverty status using the LATE Estimation

\begin{tabular}{|c|c|c|c|c|c|c|c|c|c|c|c|c|}
\hline & \multicolumn{2}{|c|}{ Area harvested } & \multicolumn{2}{|l|}{ Rice Output } & \multicolumn{2}{|l|}{ Yield } & \multicolumn{2}{|c|}{ Household Expenditure } & \multicolumn{2}{|c|}{ Per Capita Expenditure } & \multicolumn{2}{|l|}{ Total Income } \\
\hline & Poor & Non-poor & Poor & Non-poor & Poor & Non-poor & Poor & Non-poor & Poor & Non-poor & Poor & Non-poor \\
\hline LARF / LATE & $0.55(0.29)$ & $0.59(0.30)$ & $\begin{array}{r}1190.10^{* * * *} \\
(4.06)\end{array}$ & $\begin{array}{r}1310.34 * * * \\
(14.22)\end{array}$ & $\begin{array}{r}-29.29 * * * \\
(0.16)\end{array}$ & $\begin{array}{r}-27.12 * * * \\
(0.00)\end{array}$ & $\begin{array}{r}11149.87 * * * \\
(176.45)\end{array}$ & $\begin{array}{r}13105.52^{* * * *} \\
(253.48)\end{array}$ & $\begin{array}{r}1179.46^{* * * *} \\
(5.59)\end{array}$ & $\begin{array}{r}1113.34 * * * \\
(0.25)\end{array}$ & $\begin{array}{r}69664.12 * * * \\
(334.53)\end{array}$ & $\begin{array}{r}65737.06 \text { **** } \\
(15.07)\end{array}$ \\
\hline Diffmo & $\begin{array}{r}1.06 * * * \\
(0.22)\end{array}$ & $\begin{array}{r}0.85^{* * * *} \\
(0.25)\end{array}$ & $\begin{array}{r}1993.91 * * * \\
(336.96)\end{array}$ & $\begin{array}{r}1002.88^{*} \\
(540.54)\end{array}$ & $\begin{array}{r}214.42 \\
(123.08)\end{array}$ & $\begin{array}{r}-151.25 \\
(156.20)\end{array}$ & $\begin{array}{r}1991.73 \\
(2518.29)\end{array}$ & $\begin{array}{r}3697.94 \\
(9857.69)\end{array}$ & $\begin{array}{r}-292.46 \\
(194.45)\end{array}$ & $\begin{array}{r}-2.62 \\
(1446.65)\end{array}$ & $\begin{array}{r}169247.70 * * * * \\
(33666.2)\end{array}$ & $\begin{array}{l}106729 * * * \\
(30779.98)\end{array}$ \\
\hline mo_N1 & $\begin{array}{r}2.51 * * * \\
(0.18)\end{array}$ & $\begin{array}{r}2.53 * * * \\
(0.18)\end{array}$ & $\begin{array}{r}3726.18 * * * \\
(294.33)\end{array}$ & $\begin{array}{r}4548.40 * * * \\
(366.71)\end{array}$ & $\begin{array}{r}1796.83^{* * * *} \\
(85.01)\end{array}$ & $\begin{array}{r}1887.44 * * * \\
(108.55)\end{array}$ & $\begin{array}{r}40974.74 * * * \\
(1899.48)\end{array}$ & $\begin{array}{r}99372.75 * * * \\
(5957.64)\end{array}$ & $\begin{array}{r}4614.64 * * * \\
(129.28)\end{array}$ & $\begin{array}{r}15987.72 * * * * \\
(906.96)\end{array}$ & $\begin{array}{l}373747 * * * \\
(27210.63)\end{array}$ & $\begin{array}{l}347618 * * * \\
(22155.16)\end{array}$ \\
\hline m0_N0 & $\begin{array}{r}1.44 * * * \\
(0.13)\end{array}$ & $\begin{array}{r}1.68^{* * * *} \\
(0.18)\end{array}$ & $\begin{array}{r}1732.26 * * * \\
(164.06)\end{array}$ & $\begin{array}{r}3545.52 * * * \\
(397.12)\end{array}$ & $\begin{array}{r}1582.41 * * * \\
(89.00)\end{array}$ & $\begin{array}{r}2038.69^{* * * *} \\
(112.32)\end{array}$ & $\begin{array}{r}38983.02 * * * \\
(1653.40)\end{array}$ & $\begin{array}{r}95674.82 * * * \\
(7853.70)\end{array}$ & $\begin{array}{r}4907.10 * * * \\
(145.25)\end{array}$ & $\begin{array}{r}15990.34 * * * \\
(1127.03)\end{array}$ & $\begin{array}{r}204499.3 * * * * \\
(19824.1)\end{array}$ & $\begin{array}{l}240889 * * * \\
(21367.18)\end{array}$ \\
\hline $\mathrm{N}$ & 245 & 294 & 217 & 217 & 191 & 213 & 248 & 301 & 244 & 303 & 242 & 299 \\
\hline N1 & 126 & 175 & 112 & 127 & 106 & 129 & 129 & 177 & 130 & 180 & 128 & 180 \\
\hline Nz1 & 175 & 217 & 155 & 153 & 144 & 149 & 178 & 222 & 180 & 222 & 178 & 221 \\
\hline
\end{tabular}

Note: Figures in parentheses are standard errors. $* * *=p<0.01 * *=p<0.05 \quad *=p<0.10$

Diffmo mean difference; N number observed; mo_N1 = adopters; N1 Number of treated; m0_N0 = non-adopters; Nz1 Number obs with inst=1; LARF Local Average Response Function 
The estimated Population Selection Bias (PSB) of 1.04 percent for those who are aware of NERICA which was statistically significant at 10 percent level among the subpopulation of farmers implies that the probability of adoption by a farmer belonging to the sub-population who are aware of NERICA is significantly different from other farmers randomly selected from the general population. The positive sign on the PSB indicates that the farmers who are aware of NERICA varieties are significantly more likely to adopt at least one NERICA varieties than any farmer randomly selected from the population. There is therefore the need to create more awareness of NERICA varieties among the rice growing communities in order to increase the adoption of these improved varieties.

In addition, we found that NERICA adopters were more technically efficient than the non-adopters with certain levels of inefficiencies still existing in both cases (those who have adopted and those who had not) in the selected states. Based on our finding, increase in labour use, quantity of seed, fertilizer and farm size are capable at increasing the technical efficiency of NERCA varieties. Adoption of NERICA significantly (at 1percent level) increased the area of land cultivated, farm output, yield, household expenditure, per capita expenditure and total farm income. This suggests that adoption of NERICA varieties has great potential for poverty reduction and improved livelihood of rice farmers in Nigeria.

\section{REFERENCES}

ADETUNJI, O. (2006). Creating appropriate technology as a means of waste minimization in cassava end products. Available at www.nifst.org/?nifst:articles (Accessed online on the 20 October, 2015)

AFDB (2014): Multinational: New Rice for Africa (NERICA) Dissemination Project. U.S. Department of the Treasury MDB Awards 2014. Available at http://www.afdb.org/fileadmin/uploads/afdb/Documents/ Project-and-

Operations/Multinational_New_Rice_for_Africa NERI CA Dissemination_Project.pdf (Accessed online March 1, 2016)

AJEWOLE, O., AYINDE, O.E., OJEHOMON, V., AGBOH-NOAMESHIE, R., \& DIAGNE A., (2015). Gender Analysis of Agricultural Innovation and Decision Making among Rice Farming Household in Nigeria. Journal of Agricultural Informatics, 6 (2):72-82. DOI:10.17700/jai.2015.6.2.179

AWOTIDE, B.A., DIAGNE A., \& OMONONA, B.T. (2012). Impact of Improved Agricultural Technology Adoption on Sustainable Rice Productivity and Rural Farmers' Welfare in Nigeria: A Local Average Treatment Effect (LATE) Technique. A paper presented at the African Economic Conference October 30-November 2, 2012 Kigali, Rwanda

ASANTE, B. O., WIREDU, A. N., MARTEY, E., SARPONG, D. B., \& MENSAH-BONSU, A. (2014). NERICA Adoption and Impacts on Technical Efficiency of Rice Producing Households in Ghana: Implications for Research and Development. American Journal of Experimental Agricultur, 4(3): 244-262. DOI: $\underline{10.9734 / A J E A / 2014 / 7250}$
AWOTIDE, B.A., Karimov, A., Diagne, A., \& Nakelse, T. (2013). The impact of seed vouchers on poverty reduction among smallholder rice farmers in Nigeria. Agricultural Economics 44.6 (2013): 647-658. DOI: 10.1111/agec. 12079

AYINDE, O. E; ADEWUMI, M.O; \& OJEHOMON, V.E.T. (2009). Determinants of Technical Efficiency and Varietal-Gap of Rice Production in Nigeria: A MetaFrontier Model Approach. Contributed Paper prepared for presentation at the International Association of Agricultural Economists Conference, Beijing, China, August 16-22, 2009.

BATTESE, G. E., \& COELLI, T. J. (1995). A Model For Technical Inefficiency Effects in a Stochastic Frontier Production Function For Panel Data. Empirical Economics, 20:325-332. DOI:10.1007/BF01205442

DALTON, T. \& GUEI, R. (2003). Productivity gains from rice genetic enhancements in West African ecologies. World Development, 31:359-374. DOI: 10.1016/S0305750X(02)00189-4

DE JANVRY, A., DUSTAN, A., \& SADOUlET, E. (2010). "Recent Advances in Impact Analysis Methods for Ex-post Impact Assessments of Agricultural Technology: Options for the CGIAR". SPIA report version 3.1. Prepared for the workshop on Increasing the rigor of ex-post impact assessment of agricultural research: A discussion on estimating treatment effects, organized by the CGIAR Standing Panel on Impact Assessment, SPIA, on Saturday October 2, 2010, Berkeley.

DIBBA, L. (2010): "Estimation of NERICA adoption rates and impact on productivity and poverty of the smallscale rice farmers in the Gambia". Unpublished thesis submitted to the Faculty of Agriculture, Department of Agricultural Economics, Agri-business and Extension in partial fulfilment of the requirements for the degree of Master of Philosophy in Agricultural Economics.

DIAGNE, A., (2006). Diffusion and Adoption of NERICA Rice Varieties in Côte d'Ivoire. The Developing Economies, XLIV (2):208-31. DOI: 10.1111/j.17461049.2006.00014.x

DIAGNE, A., MIDINGOYI, G. S., \& KINKINGNINHOUN, F. (2009a): "The Impact of NERICA Adoption on Rice Yield in West Africa: Evidence from four countries". Paper presented at the International Association of Agricultural Economists, Beijing, China, August, 16-22

DIAGNE, A.; S. A. ADEKAMBI; F. P. SIMTOWE \& BIAOU, G. (2009b). "The Impact of Agricultural Technology Adoption on Poverty: The Case of Nerica Rice Varieties in Benin". A shorter version of the paper is being presented as contributed paper at the 27th Conference of the International Association of Agricultural Economists. August 16-22, 2009. Beijing, China.

DIAGNE, A., MIDINGOYI, S. K., WOPEREIS, M. \& AKINTAYO, I. (2010). Increasing Rice Productivity and Strengthening Food Security through New Rice for Africa (NERICA). Africa Rice Report. Coutonou-Benin DONTSOP, N.P.M., (2011). Impact of Adoption of Nerica Rice Varieties on Rice-Farming Households' Welfare in 
Nigeria. Published Ph.D. dissertation, Lambert Academic Publishing (LAB) GmbH \& Co. KG.

DONTSOP, N. P. M., DIAGNE, A., OKORUWA, V. O., \& OJEHOMON, V. (2011): "Impact of Improved Rice Technology on Income and Poverty among Rice Farming Household in Nigeria: A Local Average Treatment Effect (LATE) Approach". Contributed paper prepared for the $25^{\text {th }}$ conference of the Centre for the Studies of African Economies (CSAE). St Catherine College, University of Oxford, UK. 20-22 March 2011.

ESSILFIE, F. L., ASIAMAH, M. T., \& NIMOH, F. (2011). Estimation of farm level technical efficiency in small scale maize production in the Mfantseman Municipality in the Central Region of Ghana: A stochastic frontier approach. Journal of Development and Agricultural Economics, 3(14):645-654. DOI: 10.5897/JDAE11.069

FEDERAL REPUBLIC OF NIGERIA (FRN) (2006). Accelerated rice production in the Niger River basin. Main Report and Working Papers, Federal Ministry of Water Resources and Food and Agriculture Organization of the United Nations - Rome, July 28, pp.1-12.

FOSTER, J. E., GREER, J., \& THORBECKE, E. (1984). A Class of Decomposable Poverty Measures. Econometrica, 52(3):761-776. Available at https://oied.ncsu.edu/selc/wp-

content/uploads/2013/03/A-Class-of-Decomposable-

Poverty-Measures.pdf (Accessed online October 20, 2016)

FOWLER, M. (2012). Assessing NERICA Adoption and Impact: the Case of the Gambia. Available at http://aladinrc.wrlc.org/bitstream/handle/1961/10542/Fo wler,\%20Meg\%20Spring\%2012.pdf?sequence $=1$

(Accessed online January 13, 2016)

KINKINGNINHOUN-MEDAGBE, F. M., DIAGNE A., \& ADEGBOLA, P. Y. (2014). Impact of NERICA Adoption on Productivity and Income in Benin: Is There Gender Difference? AETA, Gender differential impact of NERICA rice varieties adoption in Benin, pg. 1-22. Available

at

http://www.ecoasso.org/articles/Kinkingninhoun2_et_al. pdf (Accessed online January 13, 2016)

KIJIMA, Y., DICK, S., \& OTSUKA, K. (2006). "How Revolutionary Is the 'NERICA Revolution'? Evidence from Uganda". Developing Economies 44(2): 252-67. DOI: $10.1111 /$ j.1746-1049.2006.00016.X

KIJIMA, Y., OTSUKA, K., \& SSERUNKUUMA, D. (2011). An inquiry into constraints on a green revolution in Sub-Saharan Africa: the case of NERICA rice in Uganda. World Development 39 (1):77-86. DOI: $\underline{10.1016 / \text { j.worlddev.2010.06.010 }}$

IMBENS, G. WOOLDRIDGE, J. M. (2009). Recent Developments in the Econometrics of Program Evaluation. Journal of Economic Literature 47(1):5-86. DOI: $10.1257 /$ jel.47.1.5

IMBENS, G., \& J. ANGRIST (1994). Identification and Estimation of Local Average Treatment Effects, Econometrica, 62(2):467-476. DOI: $10.3386 / \mathrm{t} 0118$

IMOLEHIN, E. D., \& WADA, A. C (2000). Meeting the rice production and consumption demands of Nigeria with improved technologies, international Rice commission Newsletter 49.
INTERNATIONAL FUND FOR AGRICULTURAL DEVELOPMENT (IFAD) (2011). Rural Poverty Report 2011: New realities, new challenges: new opportunities for tomorrow's generation. Rome: IFAD.

MENDOLA, M. (2007). Agricultural technology adoption and poverty reduction: A propensity-score matching analysis for rural Bangladesh. Food Policy 32 (2007): 372-393. DOI: 10.1016/j.foodpol.2006.07.003

NATIONAL CEREAL RESEARCH INSTITUTE (NCRI) (2004). Training manual on rice production produced for the Presidential Initiative on Paddy Production for Abakiliki and Omor rice mills and other rice processors in south east zone of Nigeria held at Umudike, Abia State, pp.1-128

OGUNGBILE, A.O., \& PHILLIP, D.O.A. (1996). A review of rice commodity systems in northern Nigeria. Report prepared for the West African Rice Development Association (WARDA)

OLOGBON, O.A.C., IKHELOA, E. E., \& AKERELE, E.O. (2012). Adoption of 'Ofada' Rice Variety and Technical Efficiency of Rice-Based Production Systems in Ogun State, Nigeria. World Journal of Agricultural Sciences, $\quad 8 \quad$ (6): $\quad 624-631 . \quad$ DOI: $\underline{10.5829 / \text { idosi.wjas.2012.8.6.1638 }}$

NEWSWATCH TIME (2014): Nigeria spends over N356bn to import rice annually. Available at http://www.punchng.com/business/industry/rice-nigeriain-race-to-meet-2015-target/ (Accessed online on the 24/10/2015)

SPENCER, D., DOWARD, A., ABALU, G., PHILLIPS, D. \& OGUNGBILE, D. (2006). Evaluation of adoption of NERICA and other improved upland rice varieties in Nigeria. Report submitted to the Gatsby and Rockfeller Foundations.

TIAMIYU, S.A., GANA, A. S. \& GBANGUBA, A. A. (2006). Modern Technology Adoption and Distribution of Income from Rice Production in Nigeria. In: L.T. Narteh, J.S. Tenywa, P. Nampala and G. Kawube (Editors) Proceeding of the Africa Rice Congress, Dar-es-Salam, Tanzania, 29 July-3 August, pp. 247-255.

TIAMIYU, S. A., AKINTOLA, J.O \& RAHJI, M.A.Y. (2010). Production efficiency among growers of New Rice for Africa in the savannah zone of Nigeria. Agricultura Tropica Et Subtropica, 43(2): 134-139.

TIJANI, A. A. (2006). Analysis of the technical efficiency of rice farms in Ijesha Land of Osun State, Nigeria. Agrekon, 45(2):126-135. DOI: $\underline{10.1080 / 03031853.2006 .9523738}$

WIREDU, A. N., GYASI, K. O., \& ABDOULAYE, T. (2010). Impact of improved varieties on yield of rice producing households on Ghana. Household Survey, Ghana. Paper presented at the second Africa Rice Congress, Bamako, Mali, 22-26 March 2010: Innovation and Partnerships to Realize Africa's Rice Potential. [Online]: Available: http://www.africarice.org/workshop/ARC/3.6\%20Wiredu \%20fin.pdf [Accessed on 20 June 2015]

WIREDU, A N., ASANTE, B.O., MARTEY, E., DIAGNE, A., \& DOGBE, W. (2014). Impact of NERICA Adoption on Incomes of Rice-Producing Households in Northern Ghana. Journal of Sustainable Development; 7(1):167-177. DOI:10.5539/jsd.v7n1p167 